\title{
American Astronomers in Belgium, 1919: Snapshots from the Founding of the IAU
}

\author{
James M. Lattis ${ }^{1}$ and Anthony J. Lattis ${ }^{2}$ \\ ${ }^{1}$ Department of Astronomy, University of Wisconsin-Madison \\ email: lattis@astro.wisc.edu \\ ${ }^{2}$ School of Library and Information Studies, University of Wisconsin-Madison \\ email: alattis@wisc.edu
}

\begin{abstract}
The USA delegation to the July 1919 International Research Council meeting in Brussels included Joel Stebbins, then professor of astronomy and observatory director at the University of Illinois, as secretary of the executive committee appointed by the National Research Council. Stebbins, an avid photographer, documented the travels of their party as the American astronomers attended the meeting and later toured devastated towns, scarred countryside, and battlefields only recently abandoned. Published reports of the meeting afterward attest to the impression left on the American visitors, and the photographs by Stebbins give us a glimpse through their own eyes. Selected photographs, recently discovered in the University of Wisconsin Archives and never before publicly seen, will be presented along with some commentary on their significance for the International Astronomical Union, which took shape at that 1919 meeting.
\end{abstract}

Keywords. Joel Stebbins, William Wallace Campbell, International Astronomical Union, Belgium, Brussels, Wisconsin, International Research Council, World War I

\section{Prelude to the Brussels 1919 Conference}

In the late summer of 1918, the First World War was tipping dramatically in favor of the allied countries, and scientists began to organize for international research efforts in a post-war world. Astronomers of the United States were involved with the organization of the International Research Council (IRC) beginning with the conference in London of October 1918. American delegates, led by George Ellery Hale, agreed with their colleagues among the Allied nations to reorganize international scientific collaborations so as to replace those that existed before the war and to exclude participation by scientists of the Central Powers $\dagger$ in any new structures. At the Paris meeting of November 1918, they agreed that the IRC would be organized into international unions, one of which was to be the International Astronomical Union (IAU). Astronomers in allied and associated countries thus prepared to meet for a constitutive assembly in Brussels in July 1919 to inaugurate the IRC and to organize the new astronomical union (see Blaauw 1994, for a fuller account).

The American section of what would become the IAU began to take form at a meeting in Washington, D.C., on 8 March 1919, called by George Ellery Hale, acting on the authority of the National Academy of Sciences. Astronomer Joel Stebbins was appointed to act as secretary for this meeting, which was intended to form a temporary executive committee, representing American astronomers, which would be formalized at the upcoming Brussels conference. Astronomer W.W. Campbell was selected to chair the executive committee, which included at first astronomers C.G. Abbot, E.W. Brown, and

$\dagger$ The Central Powers consisted of the German Empire, the Austro-Hungarian Empire, the Ottoman Empire and the Kingdom of Bulgaria. 
Stebbins, again acting as secretary, and was later expanded to include a number of others, some of whom would travel to Brussels as delegates. This executive committee created 19 subcommittees that were assigned to prepare reports on specific subject areas as preparation for the Brussels meeting. Representatives at the Washington meeting also agreed to the sentiments expressed at the London conference in favor of the exclusion of scientists from the Central Powers in post-war conferences and organizations. Neutral nations were to be invited to join.

The final preparatory meeting of the American astronomers was held again in Washington shortly before the delegation's departure. That meeting, on 23-24 June 1919, received and discussed the subcommittee reports for the instruction of the Brussels delegation. Quite aside from its organizational functions, Stebbins "found it to be one of the most interesting and instructive scientific conferences" in his experience because "each report was more or less a summary of current activity in this country in different lines" from which it became evident "that astronomy knows no state boundaries." (p. 601) His expression of scientific ecumanism, however, could not carry over easily into the pending business of the nascent IAU, which would take place amid the destruction barely eight months after the end of the war.

\section{Post-war attitudes}

Despite acknowledging the importance of transnational collaboration in astronomy, Stebbins found himself in a complicated situation with regard to how astronomers of the Central Powers should be received in international science, if at all, after the war. His former thesis advisor and mentor, W.W. Campbell, argued stridently and openly that German scientists bore a full burden of guilt for justifying and supporting their country's policies and actions and argued for indefinite postponement of any relations (Campbell 1919). Campbell was far from detached in his judgement, having a son serving in combat in Europe, and he made his opinions well known to Stebbins by correspondence and, almost surely, in person. He would, by late 1919, nominate Stebbins to the National Academy of Sciences and see to the successful election of the relatively young astronomer into the elite organization.

But Campbell was at one extreme of a spectrum of opinions about post-war relations with scientists from former enemy nations, the other extreme arguing in favor of restoring relations and collaborations as soon as possible after the ending of hostilities. Stebbins's own opinion seems to have been somewhere in between. He was a protege of Hale, whose attitude, though expectant of contrition and humility from German scientists, was considerably less emotional than Campbell's and aimed to accelerate post-war collaborations. Stebbins himself had professional and friendly relations with German astronomers dating from his sabbatical year, 1912-1913, spent mostly in Munich studying with Hugo von Seeliger. Stebbins had maintained friendly correspondence with German colleagues right into early 1915 and had learned a great deal from such pioneers in photoelectric photometry as Paul Guthnick at Berlin and Hans Rosenberg in Tübingen. Quite aside from any obligations of friendship, which he always took seriously, Stebbins needed to stay in touch with technical and scientific developments in Germany.

Stebbins sought to have it both ways to some extent by agreeing with Campbell in their personal correspondence, but at the same time excusing himself from taking a public position:

"I heartily endorse every sentiment, but not having had a son at the front and not having done anything in particular myself, I have preferred to let someone else explode on the matter. There are those in this country who are quite ready to resume 
relationships with our old friends, but I at least shall not take any initiative in that direction." $\dagger$

His direct experience of the war's effects during the Brussels conference might have helped move Stebbins toward this more isolationist position, but it is interesting that he still only foreswore taking the initiative and did not pledge to abstain from politically problematic collaborations. In any case, by 1922, Stebbins would again be undertaking friendly correspondence with Germans, arranging arrivals in Wisconsin for German visitors, and enthusiastically helping to host such distinguished guests as Arnold Sommerfeld at the University of Wisconsin.

\section{The voyage to Brussels}

The accounts of Stebbins (1919) and Campbell (1919) describe many of the experiences and impressions of the American astronomers at the Brussels 1919 conference. Though perfectly consistent with each other, their accounts differ dramatically in tone and detail. Campbell's commentary is stern and didactic, whereas that of Stebbins is conversational, more detailed, and even humorous, with anecdotes about lodging peculiarities, extracurricular activities, and linguistic encounters. The account by Stebbins, published in the semi-professional journal Popular Astronomy, also features several photos, including the party aboard ship and at Ostend, and one of the sites of the meetings, the Palais des Académies, in Brussels. Since the photos are unattributed in the article, we assume that they are taken by Stebbins himself, and their close resemblance to the photos discussed in the present paper confirm that.

Stebbins was an avid photographer and took a number of interesting photos during the course of the trip. The negatives of some of his photos survive in the University of Wisconsin Archives and provide a glimpse of the founding meeting of the IAU through the eyes of the American astronomers. $\ddagger$ There were probably at least two photographers among the American party. Not only does Stebbins appear in a few of the photographs, but in some photographs another camera is visible. Stebbins is holding a camera in one dramatic photo (Fig. 1). We have not been able to distinguish between negatives Stebbins took with his own camera, those taken by someone else using Stebbins's camera, and negatives perhaps exchanged with the other photographer, whose identity remains uncertain, although Dorothy Mendenhall, who appears in one photo holding a camera, is a good candidate (Fig. 2).

Two days after the signing of the treaty between Germany and the Allies at Versailles, the delegation departed New York City on 30 June aboard Cunard's S.S. Aquitania. The American astronomers were no doubt aware of their vessel as sister ship, and hence vivid reminder of, the Lusitania, notoriously torpedoed and sunk by a German submarine in 1915. Aquitania was still technically in war service as a troop transport, but relatively few passengers were sailing eastward by that time. The Aquitania arrived in London on 7 July with the American astronomers. The group aboard the Aquitania (Fig. 3) comprised Campbell, director of Lick Observatory, his wife, Elizabeth, Walter S. Adams, Frederick H. Seares, and Charles E. St. John, all of Hale's Mount Wilson Observatory, as well as Benjamin Boss, Dudley Observatory, Samuel A. Mitchell, McCormick Observatory, Frank Schlesinger, Allegheny Observatory, and of course Joel Stebbins, then director of the University of Illinois Observatory, which he would leave in 1921-1922 for Wisconsin's

$\dagger$ Stebbins to Campbell (1919), 4 Nov 1919.

$\ddagger$ All photos reproduced courtesy of University of Wisconsin-Madison Archives. Many of the images can be found at University of Wisconsin-Madison Digital Collections using keywords "Stebbins World War I" at http://digital.library.wisc.edu. Eventually all of the photos should be available in this way at the same site. 


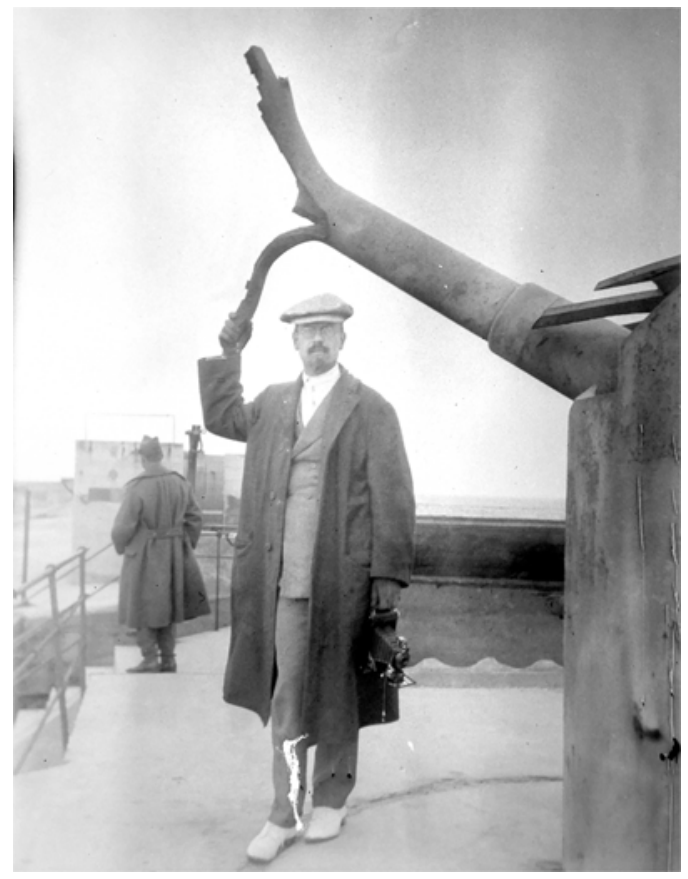

Figure 1. Joel Stebbins with camera posing by ruined gun.

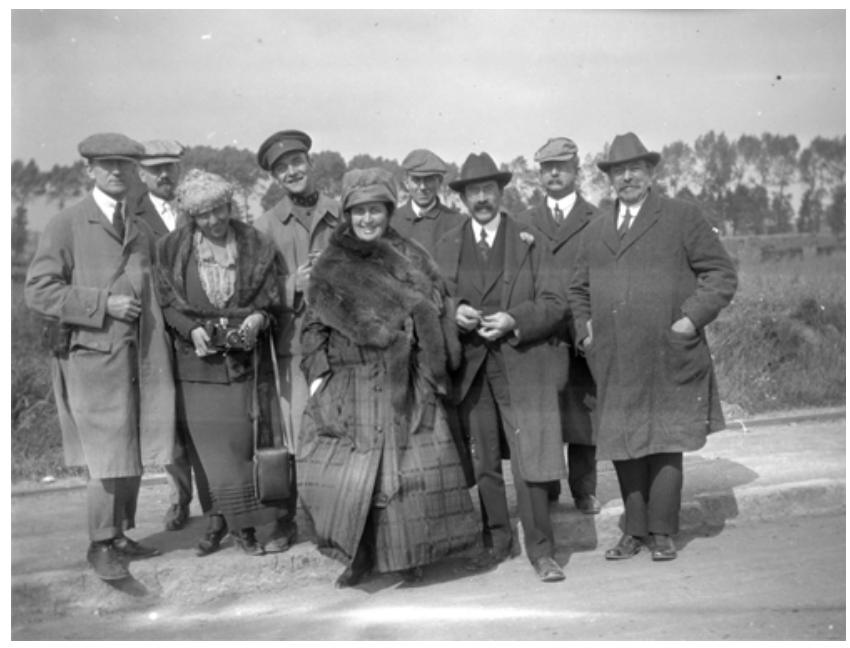

Figure 2. Group of nine posing by roadside. Left to right: Seares, Stebbins, Dorothy Mendenhall (holding camera), Fox, Mrs. Campbell, Charles Mendenhall, Astronomer Royal Frank Dyson, Greenwich astronomer Philip Cowell, Cambridge astronomer Hugh Newall.

Washburn Observatory. Also in the company were E.W. Washburn (no relation to the observatory of the same name) and C.L. Parsons, American delegates to the International Chemical Union.

The voyage itself strengthened connections between the American astronomers, some of whom had never met and others who had not seen each other, Stebbins tells us, since the 1913 meetings in Bonn and Hamburg. During the week of the voyage they held daily meetings to discuss matters that would come up in the conference. Already mentioned in the party was Dorothy Reed Mendenhall, M.D., of Madison, Wisconsin, a physician with 


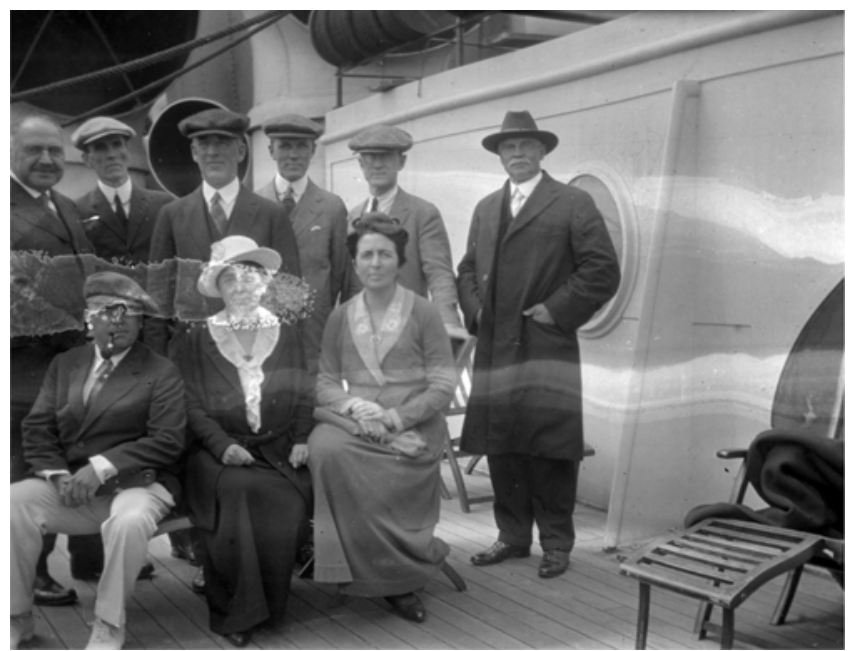

Figure 3. Delegation aboard Aquitania. Top row from left: Schlesinger, Adams, Campbell, Mitchell, Seares, St. John. Seated from left: Boss, Mrs. Campbell, Mrs. Mendenhall. Compare to group photo (Stebbins (1919) PA 603), which shows the same group in the same setting but with the addition of Stebbins.

ties to the University of Wisconsin medical school, who was sailing to join her husband, physicist Charles E. Mendenhall. He was then serving as the science attaché at the US Embassy in London, on leave from his faculty position at the University of Wisconsin, from which he had been absent for most of the war while engaged in military research. Mendenhall met the Aquitania, bearing his wife, on its arrival, and the couple would join the delegation to Brussels, where Mendenhall served as chair of the American section of the Physics Union.

Stebbins relates that the American astronomers were lavishly entertained during their stay in England, 8-16 July. A meeting and banquet with the Royal Astronomical Society, tours of observatories, and trips to Cambridge and Oxford universities, not to mention meetings about the impending conference in Brussels, occupied their time. Though they saw some bomb damage in London, their first real encounter with the consequences of war came during their London to Brussels passage on 17 July in the company of the British delegation. The channel crossing to Ostend was unusual, as Stebbins tells us, in that the ferry went straight to Calais, then passed along the coast to Ostend to avoid stray mines. At Ostend, the train station, though damaged, was in operation, and there they got the train to Brussels (Figures 4 \& 5).

Arriving in Brussels they were met by Georges Van Biesbroeck, who was actually in transition to Wisconsin owing to his impending relocation to Yerkes Observatory, in Williams Bay, Wisconsin. He proved valuable at the conference because of his technical competence as an astronomer, who was also fluent in several languages. Stebbins remarked that "it was interesting to note how he could summarize a speaker's remarks, and often improve upon the original in the translation." (p. 608) The American party was soon reinforced by the arrival of Lt. Col. Philip Fox, director of Dearborn Observatory, of Northwestern University, but then serving as assistant chief of staff, US 7th Infantry.

\section{The Brussels meeting}

The conference to complete the organization of the IRC and form international unions for individual scientific disciplines convened in Brussels on 18 July 1919. Some 200 representatives from 11 countries attended the sessions, which met in the Palais des Académies, 


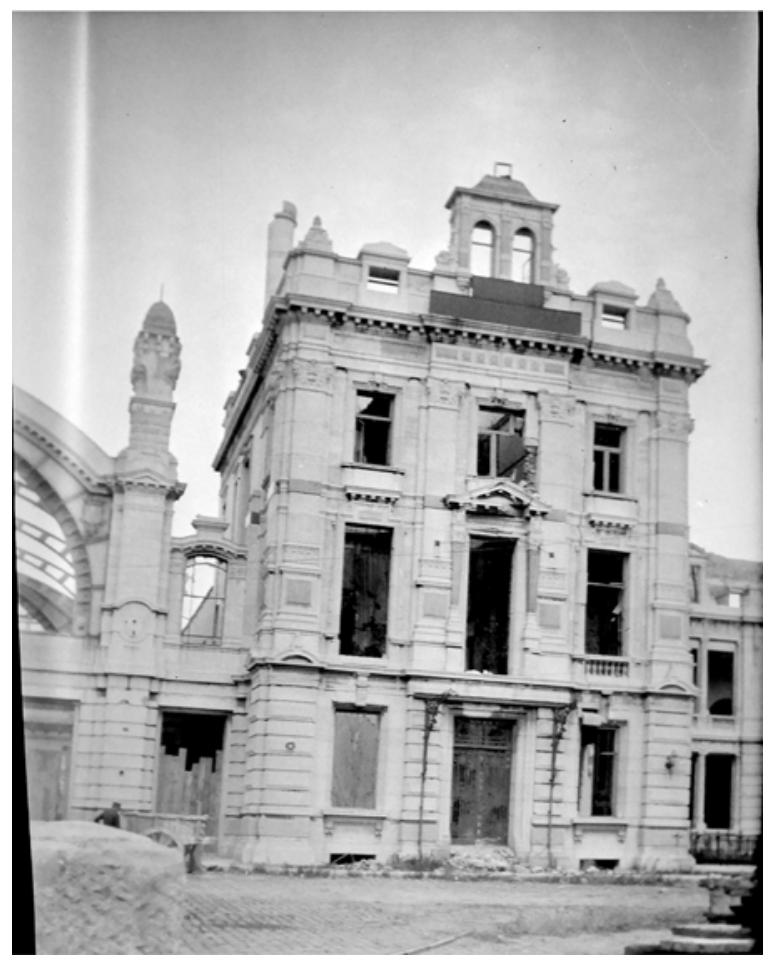

Figure 4. Damaged train station at Ostend.

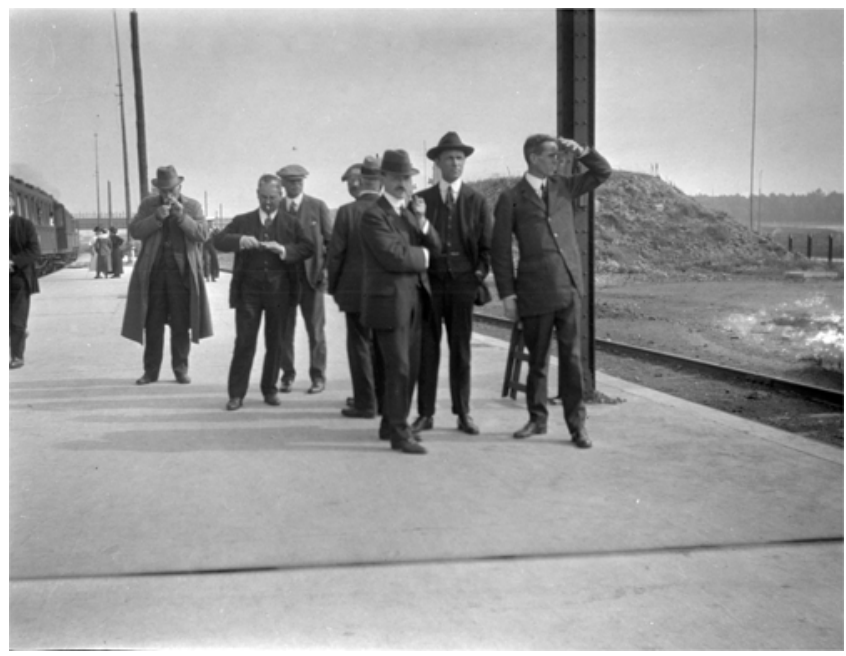

Figure 5. Party of eight on Ostend train platform. Left to right: St John, Boss, Cowell, Schlesinger, (unknown, back to camera), Fowler, Mitchell, Adams. Compare to group from a different angle (Stebbins (1919) PA 605).

a five-minute walk from the Americans' hotel, the Grand Hôtel Brittanique (Fig. 6), which no longer exists but stood at Place du Trône 3 (Fig. 7). The walk to the Palais going along Place du Trône passed the old Royal Stables (Fig. 8), which are now the Archives and Library of the Academy. King Albert I attended the opening session of the conference but did not speak, much to the disappointment, Stebbins tells us, of the assembled Americans. 


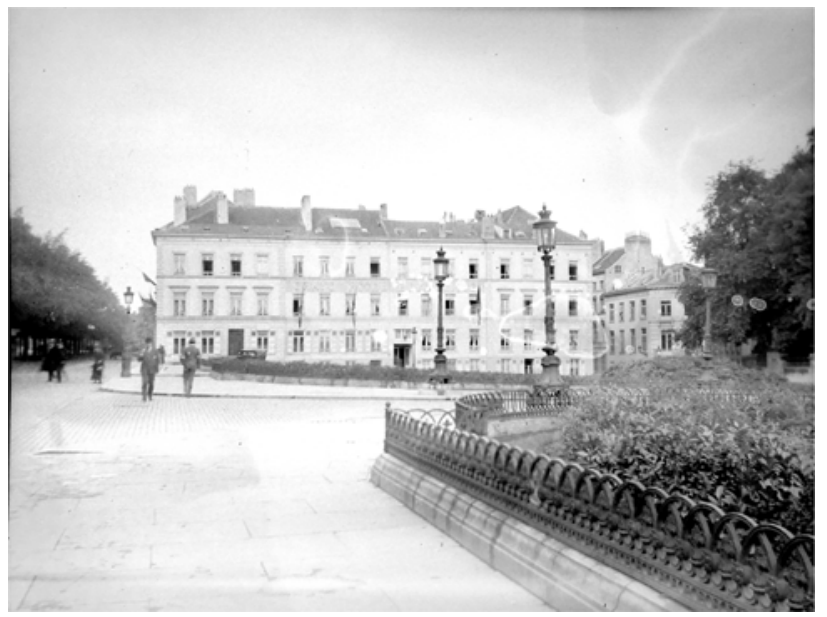

Figure 6. Grand Hôtel Brittanique at Place du Trône, 3, Brussels.

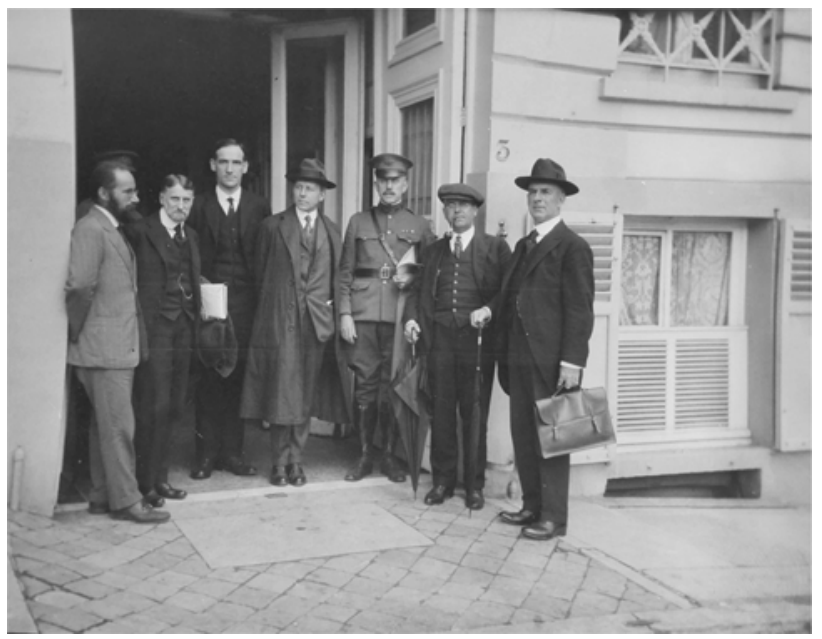

Figure 7. Party of eight at hotel entrance. Left to right: Georges Van Biesbroeck, (unknown), chemist Frederick G. Cottrell, Mitchell, geodetic engineer Maj. William Bowie, Boss, Campbell.

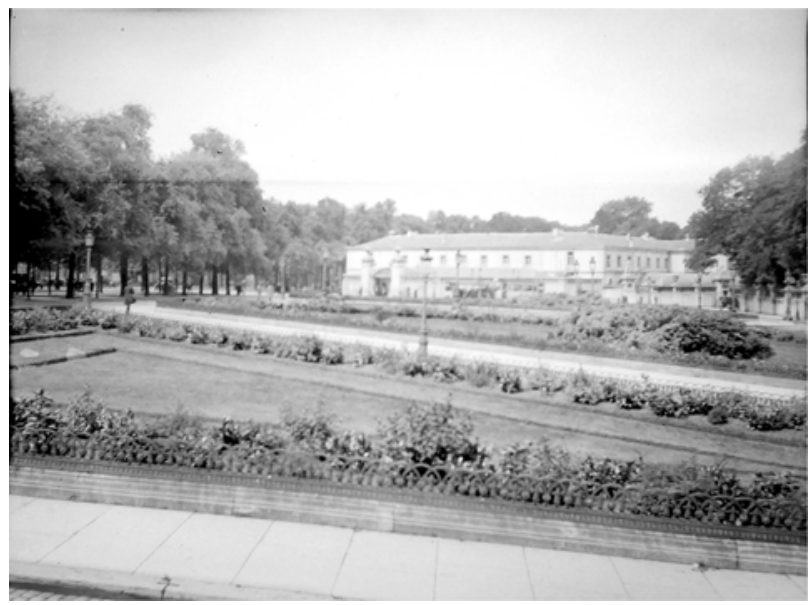

Figure 8. Royal Stables looking roughly NE from the hotel. 


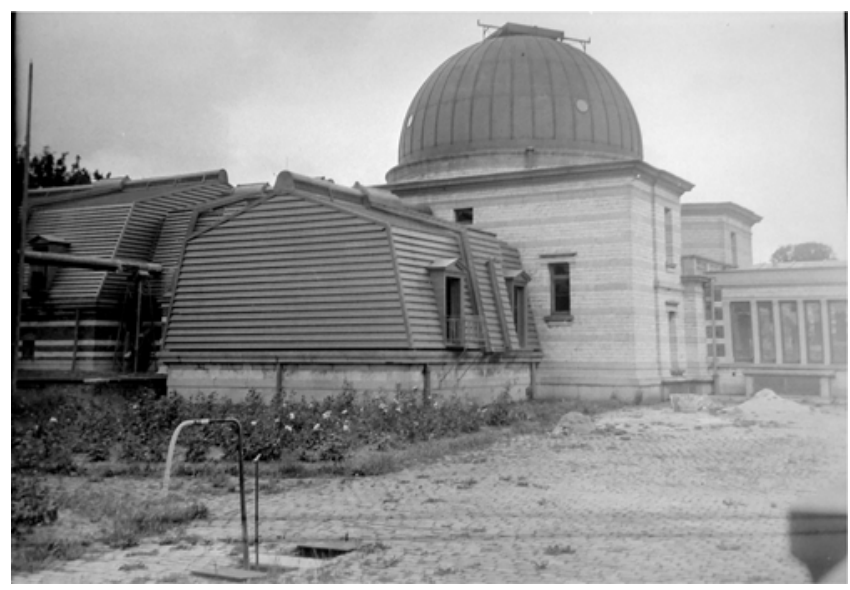

Figure 9. Royal Observatory of Belgium.

The business and outcomes of the historic conference have been covered in more detail elsewhere (e.g., Blaauw 1994). Stebbins remarked that "very little but organization was accomplished" (p. 612), perhaps reflecting disappointment that the scientific reports carefully prepared by the Americans received little discussion. But the organizational accomplishments were nonetheless essential. The conference first formalized the IRC and then established three scientific unions: the IAU, of course, the International Geodetic and Geophysical Union, and finally one for Pure and Applied Chemistry. Groundwork for additional unions was also laid. In the end, the astronomers elected Benjamin Baillaud, director of the Paris Observatory, as the first president of the newly formed IAU, named Campbell as among the first group of vice-presidents, and agreed to assemble in Rome in 1922 for the first actual IAU meeting.

As in England, the American astronomers were kept busy with social events when they were not working on the affairs of the conference. They received, of course, a tour of the Royal Belgian Observatory, at Uccle, and also enjoyed a reception by director Georges Lecointe and his wife, Charlotte, at the observatory residence (Fig. 9). Another event was an elaborate soirée, which included a concert and art exhibition, at the Hôtel de Ville hosted by the mayor of Brussels.

\section{The tours}

On the Sundays within the conference (20 \& 27 July), the American astronomers, no doubt like many other visitors, journeyed to Louvain and Dinant, "places made famous by Kultur" in Campbell's acerbic phrase (p. 256). These cities had become symbols owing to the damage they suffered during the war. These visits helped stoke the hostility directed at German scientists, who were seen by many Allied scientists, like Campbell, as sharing the blame for German militarism.

Many of Stebbins's photos document one or more automobile day trips after the end of the conference in which they ventured as far east as Liège (Fig. 10). These were guided by Maj. Frederick J.M. Stratton, an astronomer from Cambridge University who had served in active duty with the British forces since the beginning of the war, including in the Ypres and Somme areas. Judging by the photos, there were at least two automobiles carrying most of the American delegation and a few of the British (Figs. 11, 12, 13). Stebbins says that after the first tour, some in the group prevailed upon Stratton to conduct another to visit "his former homes, varying from chateaus to dugouts" in the war-torn region (p. 612). The photos show moments from both of these tours, which 


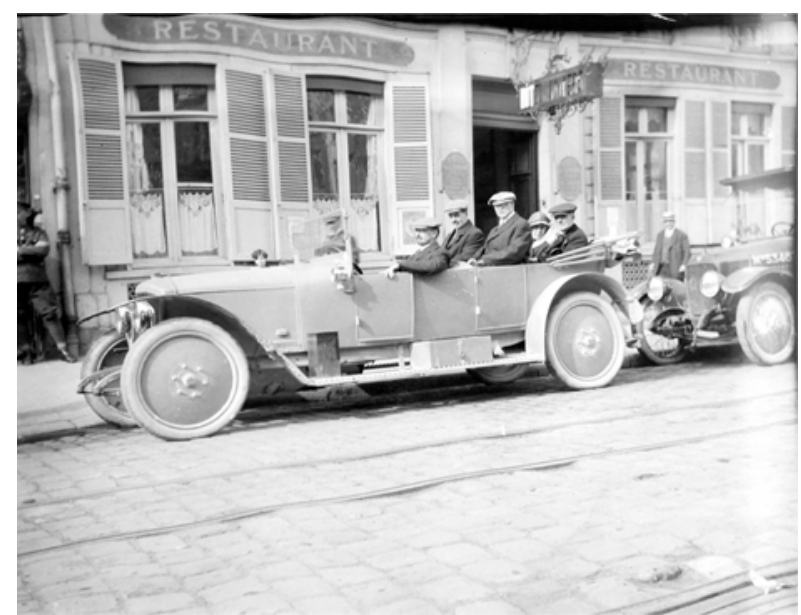

Figure 10. Party of five in car. The Hôtel de l'Univers, Liège, in background. Left to right: Stebbins (at the wheel), Dyson, Cowell, Mrs. Campbell, Campbell.

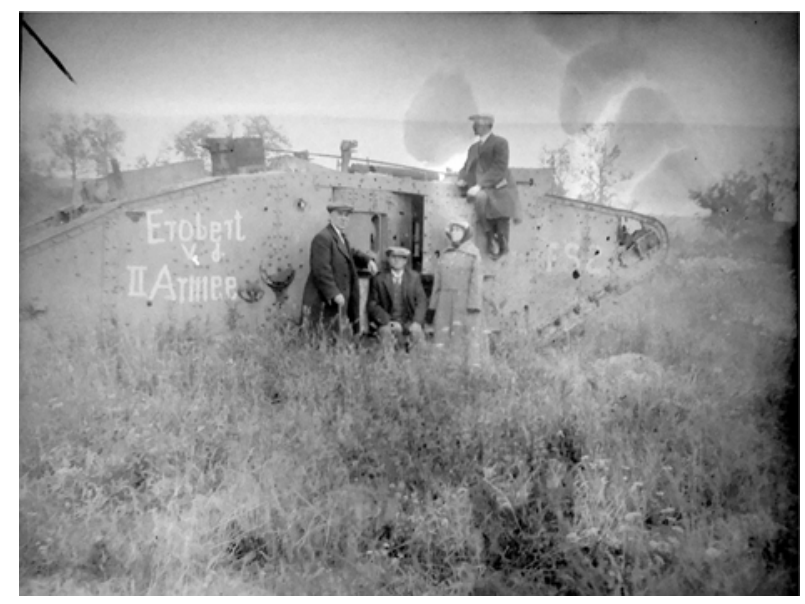

Figure 11. Abandoned British tank. Left to right: Campbell, Seares(?), Mrs. Campbell, Stebbins (atop tank).

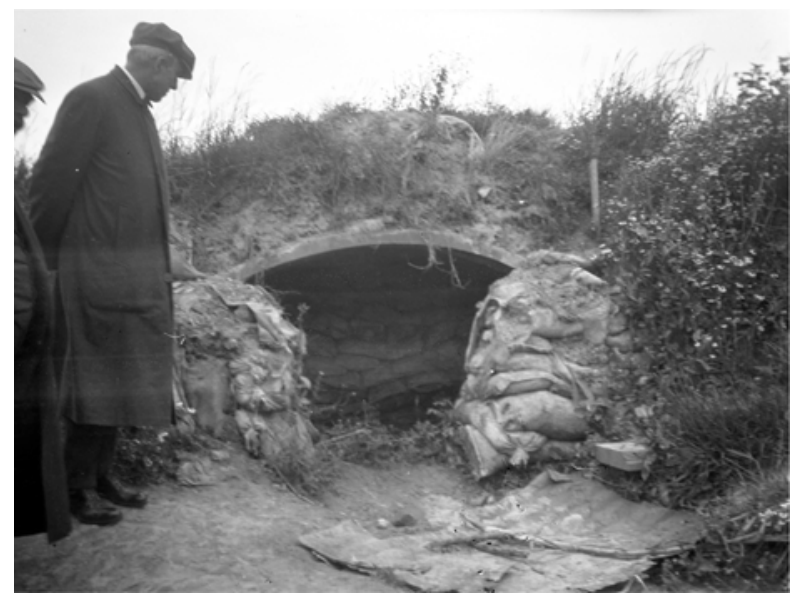

Figure 12. Abandoned battlefield fortification. Campbell on left. 


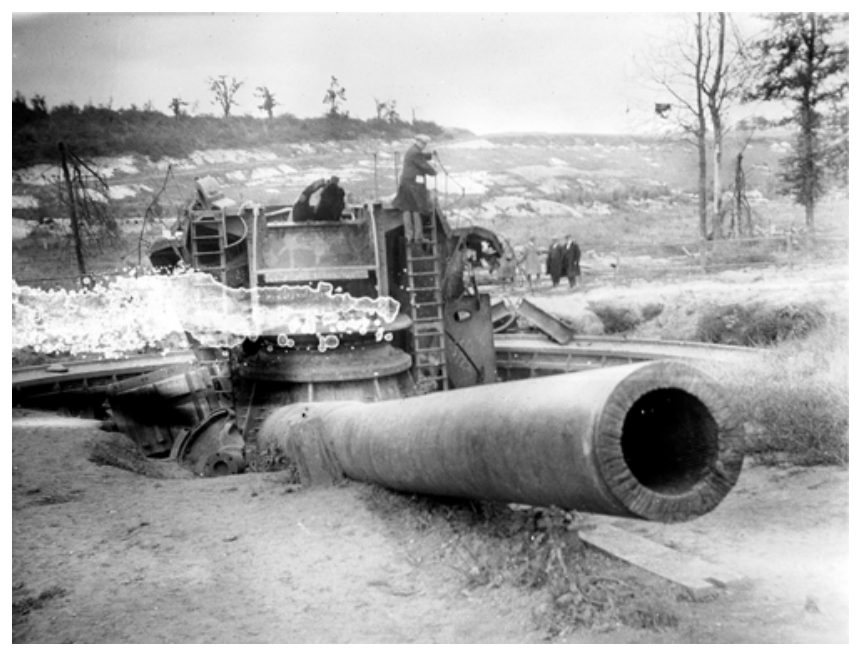

Figure 13. Abandoned artillery.

included Bruges, Zeebrugge, Ypres, and the Somme area east of Amiens. The impact of the tours validated, for Stebbins, the exclusion from the IRC of the nations of the Central Powers, whose fault in starting the war he apparently did not question:

"Certainly after seeing the devastation in Belgium and France there were none of us who felt that any peace terms could be too severe upon the originators of the war" (p. 612).

\section{Impact of the photos}

That the question of German war guilt was alive in Stebbins's mind is borne out by the group's engagement with the popular activity of battlefield tourism. In fact, it is apparent that a cottage industry of battlefield tourism, photography, and memorabilia developed rapidly in the post-war period. A packet of folded paper labelled "dirt from the Somme" containing a small amount of dusty soil, included with the negatives of Stebbins's photos and other personal effects in the University of Wisconsin-Madison Archives, attests to the desire for memorabilia.

Stebbins and his party were taking part in what was a collective exercise at the time. The commemoration of war damage served a number of ends. Images of destruction tend to have a certain romantic appeal even without a political nature, but the question of war guilt and the justification of the Versailles Treaty's punitive nature were also evoked by the circulation of poignant images. Geopolitics notwithstanding, ruin photography was quite simply in demand. Many of the sites visited by Stebbins's party appear in other collections of ruin photography, which were distributed as books, albums, postcards, stereopticon cards, and other print media. In some cases, Stebbins chose to place his camera almost exactly where other photographers had captured their famous images. For example, bombed out houses on the Grande Place in Péronne (Fig. 14) made a photogenic example of war weariness and damage. In Péronne, retreating German soldiers left a sign bearing an old saying: "Nicht ärgern nur wundern!" $\dagger$, which was frequently photographed, and Stebbins added his own picture of almost exactly the same scene, though the sign had been removed by the time he arrived. Similarly, the Cloth Hall in Ypres (Fig. 15) became iconic in the years following the war - the unique profile of

$\dagger$ Don't seeth, just wonder! 


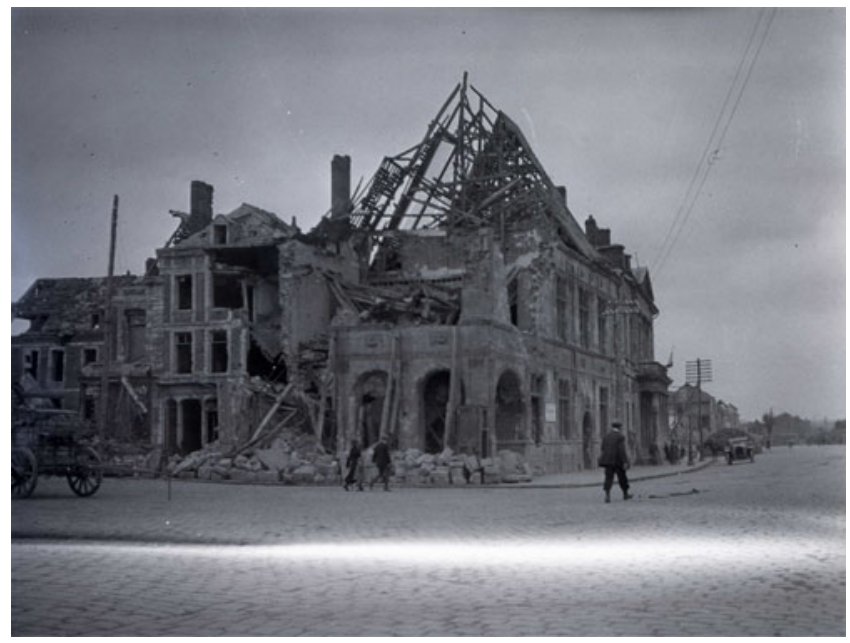

Figure 14. Grande Place, Péronne, France.

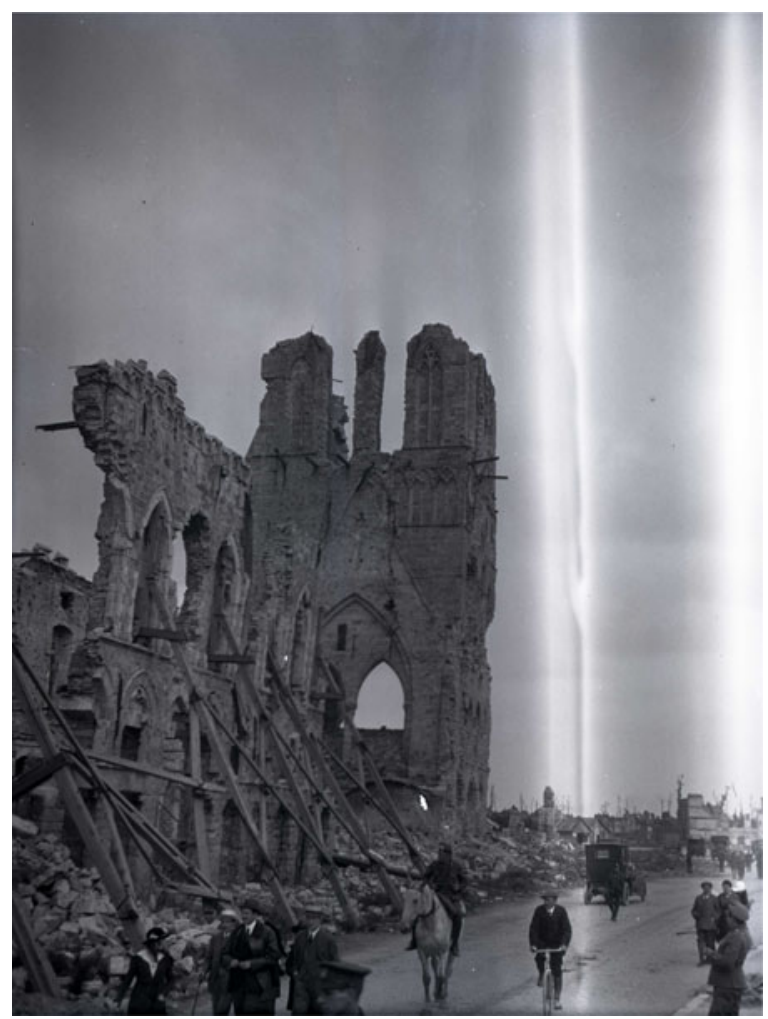

Figure 15. Ruins of the Cloth Hall, Ypres, Belgium.

its blasted belfry is recognizable in numerous articles of war memorabilia, and Stebbins photographed it from the same viewpoint as many others. Stebbins also photographed a famous sign in Villers Carbonnel (Fig. 16), a small town in the Somme department which had been completely destroyed. The unknown sign maker underlined the word "was" to emphasize that the town no longer existed. That sign itself now resides in a war memorabilia collection in the Australian War Memorial, in Campbell (near Canberra), Australia, 


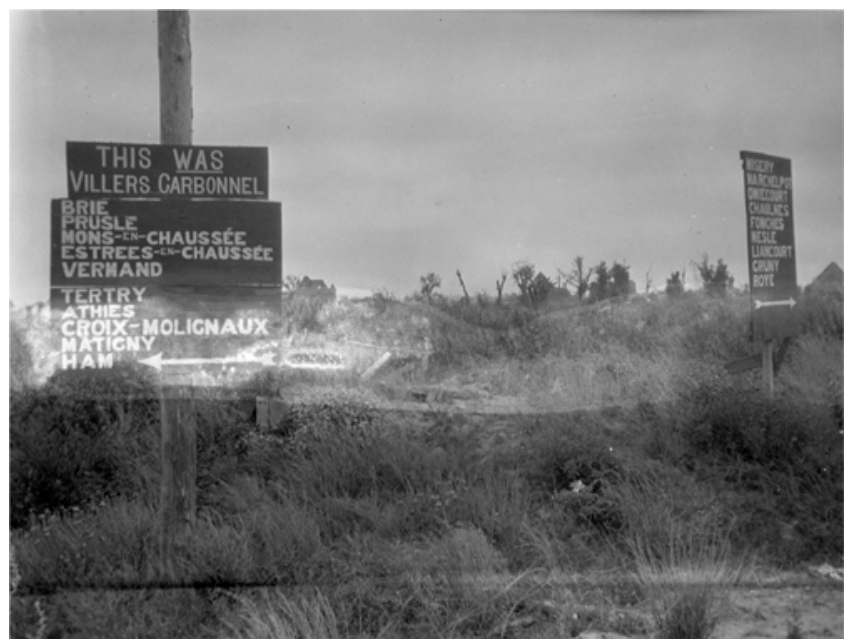

Figure 16. Villers Carbonnel, on the Somme River, France.

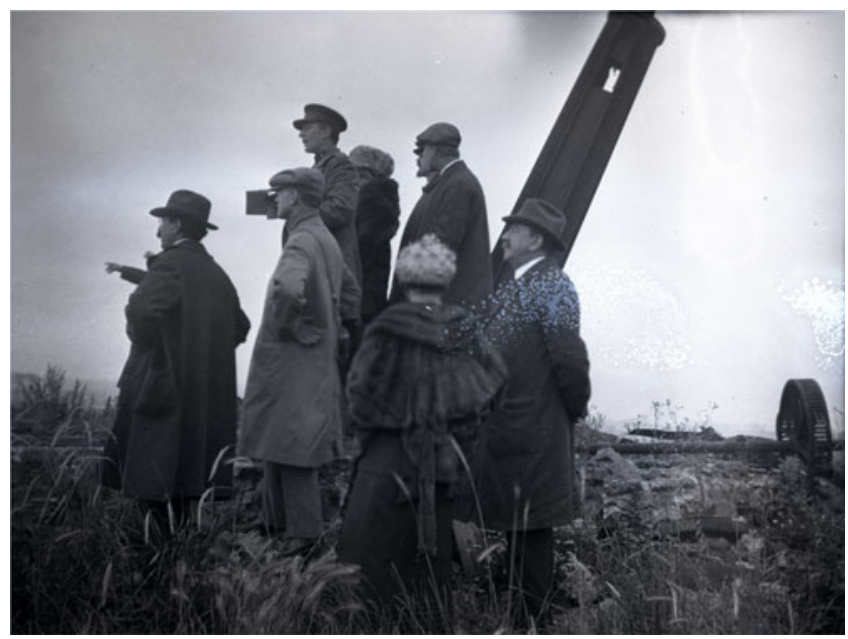

Figure 17. Battlefield site. Left to right: Fowler, Seares, Fox, Mrs. Campbell, Stebbins, Campbell, Newall. Mrs. Mendenhall in foreground, back to camera.

carried there probably by a soldier returning home. As a result of their adventures in battlefield tourism, Stebbins and his compatriots carried home their photos along with their intense memories - vivid reminders of the terrible war so recently ended (Fig. 17).

\section{Discussion}

Sterken: I met Georges Van Biesbroeck (1880-1974) in January 1973 at the Lunar and Planetary Laboratory in Tucson. He told me that he was offered the means to construct and direct a large observatory in Ghent, Belgium, but he decided to flee to Utrecht in the Netherlands. He sailed with his spouse and two young kids from Rotterdam to arrive on Ellis Island on June 20, 1917 with final destination "Observatory" Williamsbay, Wisconsin. Born and raised in Ghent, he recorded "Flemish" under the heading Race or People in the List or Manifest of Alien Passengers for the United States Immigration Officer at Port of Arrival. In 1973 he admitted that he had entirely lost his command of the Dutch language, and our entire meeting was thus conducted in French. His short stay in Belgium in 1919 was to arrange for his permanent transfer to the Yerkes Observatory. 
LATTIS: Stebbins mentions Van Biesbroeck's transitional identity in his published account.

\section{Acknowledgements}

The authors wish to thank the University of Wisconsin-Madison Archives and the University of Wisconsin-Madison Memorial Library Special Collections Department. We are also grateful for the encouragement, assistance, and good advice from Chris Sterken.

\section{References}

Blaauw, A. 1994, History of the IAU, Dordrecht, Boston, and London: Kluwer

Campbell, W. W. 1919, Publications of the Astronomical Society of the Pacific, 31, 249-256

Stebbins, J. 1919, Popular Astronomy, 27, 601-612

Stebbins to Campbell, 4 Nov 1919, Stebbins Correspondence 1915-1959, Box 129, Shane Archives of the Lick Observatory 